Gaetano Di Martino, Associate Professor

Università degli Studi di Napoli Federico II, Italy

\title{
PROTECTION OF INCAPACITATED PERSONS: EVOLUTION OF LAW AND FUNDAMENTAL RIGHTS
}

\begin{abstract}
Summary
The evolution of medical, social and economic sciences and, more generally, of reasoning has profoundly changed the relationship between society and people with disabilities: these persons have turned, from recipients of social protection and care into active part of society. Their full and effective participation is assured on an equal basis with others. That has redeveloped the issue of disability in protecting human rights, as is also demonstrated by the UN Convention on the Rights of persons with disabilities. Consequently, to promote their full integration, international and European laws have recognized the right to their self-determination. A new balance must be found between the vulnerable persons' aspirations to decide and the support provided by the law. This reference is obviously made to the extension of the management powers that are attributed to the guardian of the incapacitated. On the one hand, the institutes of protection of the persons with disabilities have changed, as much limiting infringement upon their self-determination. On the other hand, the protection of human dignity and the full realization of the person arouse complicated questions on the exercise of the rights of the disabled: sometimes, both regarding non-patrimonial important choices - for example, medical treatment - and also patrimonial ones, where the power to decide must be attributed to the legal representative. Consequently, it is necessary to identify the basis and limits of these powers to grant people with disabilities real, instead of just apparent protection. The themes clearly involve ethical, political and religious values and, therefore, legal ones.
\end{abstract}

Keywords: protection, incapacitated, fundamental rights, evolution of law, very personal acts, choices about health treatments

\section{Introduction}

The ONU Convention on the Rights of Persons with Disabilities ${ }^{1}$ enforces "respect for inherent dignity, individual autonomy including the freedom to make one's own choices, and independence of persons" (Article 3). This Convention was implemented by the European Union, which approved it with a 2010 Council Decision $^{2}$.

ONU Convention on the Rights of Persons with Disabilities. Signed in New York on 13.12.2006. Available at: https://www.un.org/ [last viewed October 16, 2019].

2 Council decision 2010/48/EC of 26 November. OJ L 2010. 27 January, No. 23/35, p. 35-36 (BG, ES, CS, DA, DE, ET, EL, EN, FR, IT, LV, LT, HU, MT, NL, PL, PT, RO, SK, SL, FI, SV). Available at: http://data.europa.eu/eli/dec/2010/48(1)/oj [last viewed October 16, 2019]. 
For its part, the Charter of Fundamental Rights of the European Union ${ }^{3}$ establishes, among other things, that "Human dignity is inviolable" (Article 1); that "The Union recognizes and respects the right of persons with disabilities to benefit from measures designed to ensure their independence, social and occupational integration and participation in the life of the community" (Article 26); and that "Everyone has the right of access to preventive health care and the right to benefit from medical treatment under the conditions established by national laws and practices" (Article 35).

The Italian Constitution recognizes the inviolable rights of man, both as an individual and in social formations (Article 2); it protects human dignity, guaranteeing the right to freedom (Article 13), the right to health and the right to refuse any medical treatment (Article 32).

The perception of disabilities and, therefore, the relationship between vulnerable persons and protective institutions changed in the Italian Law too: the amministrazione di sostegno (also known as a.d.s.) was introduced in Italy by Law No. $6 / 2004^{4}$, due to protect "with the least possible limitation of the ability to act, people who are wholly or partly lacking autonomy in the performance of the functions of daily life, through temporary or permanent support interventions". The legislation incorporates some solutions of the Sauvegarde de Justice, which represents one of the institutions for the protection of incapacitated subjects within the ambit of the French legal system. However, the influence of the Austrian Sachwalterschaft and the German Betreuung was really important.

The amministrazione di sostegno (translated as "support administration") represents a more modern and adequate measure compared to the traditional forms stipulating incapacity in the Italian civil code, i.e. interdizione and inabilitazione. The a.d.s. establishes a more flexible model of protection of the person, ensuring a greater respect of his dignity. Aiming for the full realization of the human person in conditions of psychic or physical vulnerability, the leading purpose of the discipline of the a.d.s. is, whenever possible, to promote the right of the person to express his will.

In the past, the law established the complete deprivation of the capacity for self-determination for people with mental disabilities; now, in the opposite sense, it provides for specific limitations on the capacity to implement legal acts. In fact, in the previous discipline, the vulnerable person as a subject of protection measures was precluded from fulfilling all or almost all the acts entrusted to the guardian. With the a.d.s., the beneficiary remains capable for all acts not prohibited by the judge.

3 Charter of Fundamental Rights of the European Union. Signed in Nice on 07.12.2000. OJ C, 26.10.2012, No. 326, p. 391-407 (BG, ES, CS, DA, DE, ET, EL, EN, FR, IT, LV, LT, HU, MT, NL, PL, PT, RO, SK, SL, FI, SV). Available at: http://data.europa.eu/eli/treaty/char_2012/oj [last viewed October 16, 2019].

4 Law 09.01.2004, No. 6. Italian OJ 19 January, No. 14, 2004. Available at: https://www. gazzettaufficiale.it [last viewed October 16, 2019]. 


\section{Support administration (a.d.s.) and other institutions for the care of the vulnerable persons}

The a.d.s. can be applied to people with mental illness, to people suffering from epileptic syndrome ${ }^{5}$, Down's syndrome ${ }^{6}$, and to severely depressed people ${ }^{7}$, also including elderly, drug addicts, and persons only affected by physical incapacity if they are unable to provide for acts in their own interest ${ }^{8}$. We have an administration of a "representative" type, which does not deprive the beneficiary of the capacity to perform a specific act, which the guardian has also been empowered to perform; besides, there is also an "assistance" or "incapacitating" type of administration," wherein only the guardian - under the control of the Court - can perform the act on behalf of the vulnerable person, who is not permitted to perform it autonomously.

Interdizione and inabilitazione are still in force but just as residual protection systems and must be ordered by the Court not depending on the severity of the incapacitation but on the basis of the concrete needs of protection of the beneficiary ${ }^{10}$. Basically, interdizione must be ordered only if the incapable person requires a more radical exclusion from the legal acts, or to preclude the performance of some important acts that cannot be properly supervised by a.d.s. For example, interdizione can be ordered to safeguard the integrity of the personal assets which, due to their importance, cannot be administrated by the person with disabilities; moreover, if necessary, it can be ordered to exclude fundamental freedoms such as marriage ${ }^{11}$.

In force of Article 411 c.c., the judge can extend the effects of rules intended for interdizione and inabilitazione to the beneficiary of a.d.s.: among these, there are the prohibition of making a will ${ }^{12}$, to make a donation ${ }^{13}$ or to acknowledge a child ${ }^{14}$.

5 Delle Monache S. Prime note sulla figura dell'amministrazione di sostegno: profili di diritto sostanziale [First considerations on Support Administration Law]. Nuova giurisprudenza civile commentata, 2004, II, p. 35.

6 Judgment of Corte di Cassazione No. 22332 of 26 October 2011. Giustizia civile, 2011, I, p. 2807; judgment of Tribunale Varese of 6 October 2009. Giurisprudenza italiana, 2010, IV, p. 846; judgment of Tribunale Busto Arsizio of 12 October 2011. Available at: dejure.it [last viewed October 16, 2019].

7 Judgment of Tribunale Bologna-Imola of 2 January 2006. Available at: www.personaedanno.it [last viewed October 16, 2019].

8 Judgment of Corte di Cassazione No. 13917 of 2 August 2012, Available at: dejure.it [viewed 16.10.2019]; judgment of Corte di Cassazione No. 25366 of 29 November 2006, ibid.

9 Cendon P. Amministrazione di sostegno. a) Profili generali [Support Administration. General considerations]. In: Enciclopedia del diritto, Annali, VII. Milano: Giuffrè, 2014, p. 28.

10 Judgment of Corte di Cassazione No. 22332 of 26 October 2011. Available at: dejure.it [last viewed October 16, 2019]; judgment of Corte di Cassazione No. 9628 of 22 April 2009, ibid.

11 See below.

12 Judgment of Tribunale Varese of 19 October 2011. Available at: www.personaedanno.it [last viewed October 16, 2019].

13 Bugetti M. N. Art. 411 [Commentary on Art. 411 c.c.]. In Commentario al codice civile. Directed by Gabrielli G. and Balestra L. (eds.), Delle persone, Artt. 343-455. Padova: Utet, 2009, p. 327.

14 Bocchini F. e Quadri E. Diritto privato [Private Law]. Torino: Giappichelli, 2016, p. 276. 
According to some judges, the prohibition of marriage $e^{15}$ or of Unione civile ${ }^{16}$ (between persons of the same sex) can also be extended to the beneficiary of a.d.s. In these cases, where fundamental rights are somehow restricted, the beneficiary requires technical assistance of a lawyer ${ }^{17}$. The right to sexuality can never be restricted ${ }^{18}$.

However, in the author's opinion, the right to marry can be restricted only with interdizione. Actually, the law declares the marriage (Article 119 c.c.) and the Unione civile (Article 1, co. 5, Law No. 76/2016) invalidity only with regard to the person declared interdetto, without references to the a.d.s. Thus, the power given to the judge by Article 411 c.c. (to extend the effects provided for by the law for interdetto) does not allow the extension of the prohibition of marriage, contrary to what was held by the judges ${ }^{19}$. The restriction of matrimonial freedom is exceptional. It should be remembered that the Charter of Fundamental Rights of the European Union recognizes the right to marry and the right to found a family (Article 9). So only a Court formed by three judges ${ }^{20}$ can forbid the marriage ${ }^{21}$. Instead, every decision on a.d.s. is pronounced by only one judge.

\section{Protection of incapacitated persons, very personal acts and fundamental rights}

The personality of the individual is also effectuated through performance of negotiation or economic activity. Consequently, there are delicate regulatory areas, some of which have emerged recently, such as choices regarding health treatments and other fundamental rights. Thus, since the beneficiary is not excluded from the legal activity, the a.d.s. discipline must be coordinated with the norms concerning the family, contracts, companies, trade, inheritance and donations.

15 Judgment of Corte di Cassazione No. 11536 of 11 May 2017. Available at: dejure.it [last viewed October 16, 2019]; judgment of Tribunale Trieste of 28 September 2007. Giurisprudenza italiana, 2007, p. 2739.

16 Introduced by Law 20.05.2016, No. 76. Italian OJ 21 May, No. 118, 2016. Available at: https:// www.gazzettaufficiale.it [last viewed October 16, 2019].

17 Judgment of Corte di Cassazione No. 19233 of 11 July 2008. Available at: dejure.it [last viewed October 16, 2019]; judgment of Corte di Cassazione No. 25366 of 29 November 2006, ibid.; judgment of Corte Costituzionale No. 128 of 19 April 2007, ibid.

18 Judgment of Tribunale Varese of 11 November 2011. Available at: www.personaedanno.it [last viewed October 16, 2019].

19 Introduced by Law 20.05.2016, No. 76. Italian OJ 21 May, No. 118, 2016. Available at: https:// www.gazzettaufficiale.it [last viewed October 16, 2019].

20 In fact, the judgment of interdizione is given by a Court formed by three judges.

21 Anelli F. Il nuovo sistema delle misure di protezione delle persone prive di autonomia [The new model of protection for vulnerable persons]. Jus, 2005, p. 220 ss. See also Di Martino G., L'amministrazione di sostegno. Inquadramento, disciplina ed effetti [Support Administration. Legal framework, regulation and consequences]. In: Capacità e incapacità. Napoli R. F. (ed.), Esi, 2018, p. 142 ss. e p. 177 ss. 
The beneficiary suffers the limitation of his own capacity only with regard to the specific acts assessed by the judge as potentially prejudicial (for example, contracts involving goods of great value).

In the Italian legal system, the guardian can only continue - but not initiate the exercise of commercial enterprise on behalf of the interdetto, both as an individual company and as a partnership. On the other hand, the beneficiary of a.d.s. can directly start and perform business activities and participate in partnerships or capital companies, if there are no specific restrictions ordered by the judge ${ }^{22}$. Sometimes, the beneficiary can be helped by the guardian ${ }^{23}$.

The balance between the opposing needs of autonomy and protection of the person becomes very complex with particular regard to the so-called "very personal" rights and juridical acts; in the Italian law, these acts traditionally do not admit the participation of a legal or voluntary representative.

In the absence of prohibitions imposed by the judge, the beneficiary of a.d.s. remains fully capable of making wills and donations ${ }^{24}$. According to some authoritative opinions, the freedom to make a will can be limited only under very exceptional circumstances, to respect the "human feeling" ${ }^{25}$. Moreover, the will is an act without prejudice to its author. The heirs, for their part, are protected by specific legal actions. They can contest the will, if its author has been non compos mentis upon completing the act.

These considerations, together with some rules contained in the civil code (Articles 602 , co. 1,603 , co. 2 , c.c.), further confirm the inadmissibility of any replacement of the guardian in drawing up the testament. In fact, that is called, by Italian law, olografo ("holograph"): it must be written only by the "hand" of testator, and every participation of another person, as well as the use of computer or mechanical systems cause the invalidity of the will (Article 602 , co. 1, c.c.). The Article 603, co 2., c.c. - which discipline another type of will, made by a public official (a notary) - also prohibits the participation of a nuncius, who normally only reports the will of the testator.

However, on an occasion, with a singular (and illegitimate) decision ${ }^{26}$, a judge has appointed a special curator of a vulnerable person (affected by amyotrophic lateral sclerosis) to convey, in a holograph will, the last wishes of the beneficiary, expressed through an ocular pointing communicator. This is an illegitimate decision, as it allowed the participation of another person in the drafting of a holograph

22 Bonilini G. Art. 411 [Commentary on Art. 411 c.c.]. In Codice civile commentato. Schlesinger A. and Busnelli F. D. (eds.), Milano: Giuffrè, 2008, p. 458 s.; Venchiarutti A., Capacità all'esercizio di impresa [dir. comm.] [Ability to act in commercial enterprise]. Available at: www.treccani.it/ enciclopedia [last viewed October 16, 2019]. Regarding jurisprudence, see judgment of Tribunale Novara of 5 December 2012. Available at: www.personaedanno.it [last viewed October 16, 2019].

23 Auletta G. Capacità all'esercizio dell'impresa commerciale [Ability to act in commercial enterprise]. In Enciclopedia del diritto, VI. Milano: Giuffrè, 1960, p. 79.

24 Judgment of Corte Costituzionale No. 114 of 10 May 2019. Available at: dejure.it [last viewed October 16, 2019].

25 Bonilini G. Art. 411 [Commentary on Art. 411 c.c.]. 2018, p. 433 s.

26 Judgment of Tribunale Varese of 12 March 2012. Famiglia e diritto, 2012, p. 492. 
will. The provisions of the law (regarding holographic will) are clearly violated and the decision of the judge of a.d.s. cannot validate a will contrary to the same law ${ }^{27}$.

The legitimacy of the intervention of the legal guardian in the fulfilment of gifts is also very doubtful. In another case, a judge authorized the guardian to proceed, in the name and on behalf of the beneficiary, with gifting of a house, after verifying the intent of the beneficiary and the absence of damage to him ${ }^{28}$. In yet another case, the guardian was authorized by the judge to donate to the daughters of the vulnerable person, in the name and on behalf of the same incapacitated, the co-ownership of a real estate property ${ }^{29}$. This appears patently illegitimate: the civil code excludes the possibility of making a donation on behalf of those who lack full capacity to dispose of their assets. It must be remembered that the Article 1 of the Protocol to the Convention for the Protection of Human Rights and Fundamental Freedoms $\mathrm{s}^{30}$ establishes that "Every natural or legal person is entitled to the peaceful enjoyment of his possessions. No one shall be deprived of his possessions except in the public interest and subject to the conditions provided for by law and by the general principles of international law".

The hazards of these kinds of acts are evident, if we consider, for example, the case of a request proposed by a support administrator who was also the brother of a vulnerable person: he asked that the person with disability would be authorized by a judge to draft a will, with the same brother as beneficiary. In this case, the Court rejected the request; according to judge, the person who was supposed to make the will was non compos mentis and, moreover, his volition was not ascertainable ${ }^{31}$.

The beneficiary can freely marry, unless there are limitations ${ }^{32}$.

According to some judicial decisions, the spouse subject to interdizione may request the separation ${ }^{33}$ or dissolution ${ }^{34}$ of the marriage through the legal guardian and with the authorization of the tutelary judge; this possibility is admitted with intent to protect the incapacitated spouse from violations of marriage obligations committed by the partner.

Barba V. Testamento olografo scritto di mano dal curatore del beneficiario di amministrazione di sostegno [Holograph will written by vulnerable person's guardian]. Famiglia, persone, successioni, 2012, p. 446.

28 Judgment of Tribunale La Spezia of 2 October 2010. Nuova giur. civ. comm., 2011, I, p. 77.

29 Judgment of Tribunale Caltagirone of 10 July 2008. Il diritto di famiglia e delle persone, 2009, p. 673, with note by Gazzoni F., I giudici, legibus soluti, autorizzano il tutore a compiere atti contra legem: è ora la volta della donazione [The Judges allow the legal guardian to do acts prohibited by law: now it was the turn of donation].

30 Protocol to the Convention for the Protection of Human Rights and Fundamental Freedoms. Signed in Paris on 20.03.1952. Available at: https://www.echr.coe.int [last viewed October 16, 2019].

31 Judgment of Tribunale Roma of 30 May 2012. Nuova giurisprudenza civile commentata, 2012, I, p. 1005.

32 Judgment of Corte di Cassazione No. 11536 of 11 May 2017. Available at: dejure.it [last viewed October 16, 2019].

33 Judgment of Cassazione No. 14669 of 06 June 2018 Available at: dejure.it [last viewed October 16, 2019]; judgment of Tribunale Padova of 15 September 2006, ibid.

34 Judgment of Corte di Cassazione No. 9582 of 21 July 2000. Giustizia civile, 2000, I, p. 3145. 
It is not excluded that the same principle could be also extended to the a.d.s.; nevertheless, in the author's opinion, such personal decisions should be expressed only by the beneficiary, if he is able to assume them, with the exclusion of any intervention by the legal guardian.

In these cases, the best way to safeguard the interests of the vulnerable person could be the legal representative's proposition of a request for compensation or the proposition of the so-called exceptio doli, which allows the rejection of the claims based on the abuse of the right; in some circumstances, that appears to be more appropriate than acting with the request of separation or divorce. Likewise, only the part of the Unione civile can ask for its dissolution, according to the Article 1, co. 24, of Law No. 40/2016, with no possibility for the support administrator to perform that very personal act.

The Law No. 6/2004 does not contain specific provisions regarding nonpecuniary acts but only provides that the choice of the guardian must be made with exclusive regard to the care and interests of the beneficiary; the same law requires the guardian to consider the needs and aspirations of the beneficiary.

Many judges, however, had recognized the power-duty of the legal guardian to express consent to any medical treatment for the beneficiary: otherwise, the recipients of the protection measures could not exercise very personal rights ${ }^{35}$. This conclusion is certainly correct and complies with the Convention for the Protection of Human Rights and Dignity of the Human Being with regard to the Application of Biology and Medicine ${ }^{36}$. The Article 6, co. 3, establishes that "where, according to law, an adult does not have the capacity to consent to an intervention because of a mental disability, a disease or for similar reasons, the intervention may only be carried out with the authorisation of his or her representative or an authority or a person or body provided for by law".

In a very well-known case in Italy, a person was in a permanent neurovegetative state and could not express any consent on artificial feeding therapies: however, the guardian requested authorization, in the name and on behalf of the beneficiary, to refuse such therapies. The Supreme Court ${ }^{37}$ affirmed that the very personal right

35 Judgment of Corte di Cassazione No. 14158 of 7 June 2017. Available at: dejure.it [last viewed October 16, 2019]; judgment of Tribunale Perugia of 20 June 2013. Repertorio del Foro italiano, 2014, voce Interdizione, inabilitazione e amministrazione di sostegno, No. 34; judgment of Tribunale Reggio Emilia of 24 July 2012. Foro italiano, 2013, I, c. 2919; judgment of Tribunale Varese of 25 August 2010. Giurisprudenza italiana, 2011, p. 1805; judgment of Tribunale Firenze of 22 December 2010. Giurisprudenza di merito, 2013, p. 2375; judgment of Tribunale Modena of 14 May 2009, ibid., 2009, p. 1837; judgment of Tribunale Prato of 8 April 2009. Giurisprudenza di merito, 2010, p. 102; judgment of Tribunale Roma of 19 March 2004. Rivista del Notariato, 2004, p. 249.

36 Convention for the Protection of Human Rights and Dignity of the Human Being with regard to the Application of Biology and Medicine. Signed in Oviedo on 04.04.1997. Available at: https:// www.coe.int/it/ [last viewed October 16, 2019].

37 Judgment of Corte di Cassazione No. 21748 of 16 October 2007. Foro it., 2007, I, c. 3025. See also judgment of Consiglio di Stato No. 4460 of 2 September 2014. Available at: https:// www.giustizia-amministrativa.it [last viewed October 16, 2019]; judgment of Consiglio di Stato No. 3058 of 21 June 2017, ibid. 
to health, by its nature, does not allow the guardian to dispose of it on the behalf of the individual in a state of total and permanent unconsciousness. Consequently, it is necessary to reconstruct the presumed will of the unconscious patient, taking into account the desires he expressed before the loss of conscience, or inferring that will from his personality, his lifestyle, his inclinations, his reference values and his ethical, religious, cultural and philosophical convictions.

Recently, the Italian legislator introduced rules to protect the freedom of choice of medical care ${ }^{38}$. According to the Article 3 of Law No. 219/2017 ${ }^{39}$, if a guardian has been appointed, the consent to treatment is expressed or refused by the same guardian, taking into account the will of the beneficiary in relation to his ability to understand. If there are no choices previously declared by the beneficiary when he was of sound mind, in case of disagreement between the legal guardian and the doctor about proposed care, the decision is left to the judge $\mathrm{e}^{40}$.

However, the Constitutional Court has ruled that the power of representation for health choices always involves the power to refuse the medical treatment necessary for the maintenance of life ${ }^{41}$. The judge must specifically evaluate the clinical conditions of the protected person and the power to refuse treatment must be specifically attributed to the guardian.

It must be emphasized that life-saving treatment can never be rejected - not even by the judge - if the beneficiary had not expressed, when he was of sound mind, the refusal of the same care, according to the provisions of Article 1, co. 4 and 5, and of Article 4 of Law No. 219/2017. The Article 1, co. 4 of the same law establishes that the consent or the refusal to the therapies must be expressed in written form or through video recordings or, in case of a person with disabilities, through devices that ensure communication. According to the Article 4, in view of a possible future incapacity of self-determination and after an adequate information any adult person who is of sound mind may express authenticated private writings or public deeds in relation to (future) health treatments, including refusal thereof. The right to refuse medical treatment is highly personal ${ }^{42}$ and can only be exercised by its owner in the forms prescribed by law. The representative can only report the will of others but cannot form it, neither directly or indirectly by its reconstruction.

38 Law 22.12.2017, No. 219. Italian OJ 2018, 16 January, No. 12. Available at: https://www. gazzettaufficiale.it [last viewed October 16, 2019].

39 About this law, see Zatti P. Spunti per una lettura della legge sul consenso informato e Dat [Reflections on Law on Living will]. Nuova giurisprudenza civile commentata, 2018, p. 247. Maffeis D. Prometeo incatenato: la redazione non informata, o informata per modo di dire, e l'attenuata vincolatività delle Dat (disposizioni anticipate di trattamento) [Drafting in an unconscious way of a Living will and non-binding rules]. Responsabilità civile e previdenza, 2018, p. 1436.

40 See also below.

41 Judgment of Corte Costituzionale No. 144 of 13 June 2019. Available at: dejure.it [last viewed October 16, 2019].

42 Judgment of Corte di Cassazione No. 12998 of 15 May 2019. Available at: dejure.it [last viewed October 16, 2019]. 
It follows from the above considerations that the very recent pronouncement ${ }^{43}$ of a judge, who "omitted" to take any decision about the support administrator's (possible) authorization to order the suspension of a therapy, is clearly wrong; according to the judge, the support administrator is fully entitled to refuse and to propose treatments, once he himself had ascertained the will of the administered person in reference to the health treatment in question (and this also presumptively, in the light of the declarations made in presence of the same administrator).

\section{Conclusions}

The freedom of the person is at the same time the purpose for and the limit of protection of that person's dignity.

The individual subjected to a.d.s. can directly perform highly personal acts, even those with patrimonial content, if in a position to decide with full lucidity; otherwise, those acts can never be executed by the guardian, even if he only carries out the will of the beneficiary. In this context, the beneficiary of the protection is the only person who can refuse medical therapies necessary for that beneficiary's survival (with the exception of the so-called "therapeutic obstinacy"); this decision cannot be left to the guardian.

The same principle can apply to other fundamental choices, such as separation and dissolution of marriage.

Self-determination is essential; that said, "substitution" in personal choices should be considered as exceptional and seen as an extrema ratio.

Opposing solutions do not grant autonomy but, on the contrary, endanger or maybe even annihilate the fundamental rights of vulnerable persons.

\section{BIBLIOGRAPHY}

\section{Literature}

1. Anelli F. Il nuovo sistema delle misure di protezione delle persone prive di autonomia [The new model of protection for vulnerable persons]. Jus, 2005, p. 163.

2. Auletta G. Capacità all'esercizio dell'impresa commerciale [Ability to act in commercial enterprise]. In: Enciclopedia del diritto, VI. Milano: Giuffrè, 1960, p. 72.

3. Barba V. Testamento olografo scritto di mano dal curatore del beneficiario di amministrazione di sostegno [Holograph will written by vulnerable person's guardian]. Famiglia, persone, successioni, 2012, p. 436.

4. Bocchini F. e Quadri E. Diritto privato [Private Law]. Torino: Giappichelli, 2016.

5. Bonilini G. Art. 411 [Commentary on Art. 411 c.c.]. In: Codice civile commentato. Schlesinger A. and Busnelli F. D. (eds.), Milano: Giuffrè, 2008.

43 Judgment of Tribunale Roma of 23 September 2019. Available at: http://www.quotidianogiuridico. it [last viewed October 16, 2019]. 
6. Bugetti M. N. Art. 411 [Commentary on Art. 411 c.c.]. In: Commentario al codice civile. Gabrielli G. and Balestra L. (eds.), Delle persone, Art. 343-455. Padova: Utet, 2009, p. 311.

7. Cendon P. Amministrazione di sostegno. a) Profili generali [Support Administration. General considerations]. In: Enciclopedia del diritto, Annali, VII, Milano: Giuffrè, 2014, p. 21.

8. Delle Monache S. Prime note sulla figura dell'amministrazione di sostegno: profili di diritto sostanziale [First considerations on Support Administration Law]. Nuova giurisprudenza civile commentata, 2004, II, p. 35.

9. Di Martino G. L'amministrazione di sostegno. Inquadramento, disciplina ed effetti [Support Administration. Legal framework, regulation and consequences]. In: Capacità e incapacità. Rossi F. (ed.), Napoli: Esi, 2018.

10. Gazzoni F. I giudici, legibus soluti, autorizzano il tutore a compiere atti contra legem: è ora la volta della donazione [The Judges allow the legal guardian to do acts prohibited by law: now it was the turn of donation]. Il diritto di famiglia e delle persone, 2009, p. 1238.

11. Maffeis D. Prometeo incatenato: la redazione non informata, o informata per modo di dire, e l'attenuata vincolatività delle Dat (disposizioni anticipate di trattamento) [Drafting in an unconscious way of a Living will and non-binding rules]. Responsabilità civile e previdenza, 2018, p. 1436.

12. Venchiarutti A. Capacità all'esercizio di impresa [dir. comm.] [Ability to act in commercial enterprise]. Available at: www.treccani.it/enciclopedia [last viewed October 16, 2019].

13. Zatti P. Spunti per una lettura della legge sul consenso informato e Dat [Reflections on Law on Living Will]. Nuova giurisprudenza civile commentata, civ., 2018, p. 247.

\section{Legislative acts}

1. Protocol to the Convention for the Protection of Human Rights and Fundamental Freedoms. Signed in Paris, on 20.03.1952. Available at: https://www.echr.coe.int [last viewed October $16,2019]$.

2. ONU Convention on the Rights of Persons with disabilities. Signed in New York on 13.12.2006. Available at: https://www.un.org/ [last viewed October 16, 2019].

3. Charter of Fundamental Rights of the European Union. Signed in Nice on 07.12.2000. OJ C, 26.10.2012, No. 326, p. 391-407. Available at: http://data.europa.eu/eli/treaty/char_2012/ oj [last viewed October 16, 2019].

4. Council decision 2010/48/EC of 26 November. OJ L 2010. 27 January, No. 23/35, p. 35-36. Available at: http://data.europa.eu/eli/dec/2010/48(1)/oj [last viewed October 16, 2019].

5. Law 09.01.2004, No. 6. Italian OJ 2004, 19 January, No. 14. Available at: https://www. gazzettaufficiale.it [last viewed October 16, 2019].

6. Law 20.05.2016, No. 76. Italian OJ 2016, 21 May, No. 118. Available at: https://www. gazzettaufficiale.it [last viewed October 16, 2019].

7. Law 22.12.2017, No. 219. Italian OJ 2018, 16 January, No. 12. Available at: https://www. gazzettaufficiale.it [last viewed October 16, 2019].

\section{Legal practice}

1. Judgment of Corte Costituzionale No. 128 of 19 April 2007. Available at: dejure.it [last viewed October 16, 2019].

2. Judgment of Corte Costituzionale No. 114 of 10 May 2019. Available at: dejure.it [last viewed October 16, 2019]. 
3. Judgment of Corte Costituzionale No. 144 of 13 June 2019. Available at: dejure.it [last viewed October 16, 2019].

4. Judgment of Corte di Cassazione No. 9582 of 21 July 2000. Giustizia civile, 2000, I, p. 3145.

5. Judgment of Corte di Cassazione No. 25366 of 29 November 2006. Available at: dejure.it [last viewed October 16, 2019].

6. Judgment of Corte di Cassazione No. 21748 of 16 October 2007. Foro it., 2007, I, c. 3025.

7. Judgment of Corte di Cassazione No. 19233 of 11 July 2008. Available at: dejure.it [last viewed October 16, 2019].

8. Judgment of Corte di Cassazione No. 9628 of 22 April 2009. Available at: dejure.it [last viewed October 16, 2019].

9. Judgment of Corte di Cassazione No. 22332 of 26 October 2011. Giustizia civile, 2011, I, p. 2807.

10. Judgment of Corte di Cassazione No. 13917 of 2 August 2012. Available at: dejure.it [last viewed October 16, 2019].

11. Judgment of Corte di Cassazione No. 11536 of 11 May 2017. Available at: dejure.it [last viewed October 16, 2019]. 12. Judgment of Corte di Cassazione No. 14158 of 7 June 2017. Available at: dejure.it [last viewed October 16, 2019].

13. Judgment of Corte di Cassazione No. 12460 of 21 May 2018. Foro italiano, 2019, I, c. 272.

14. Judgment of Cassazione No. 14669 of 6 June 2018 Available at: dejure.it [last viewed October $16,2019]$.

15. Judgment of Corte di Cassazione No. 12998 of 15 May 2019. Available at: dejure.it [last viewed October 16, 2019].

16. Judgment of Consiglio di Stato No. 4460 of 2 September 2014. Available at: https://www. giustizia-amministrativa.it [last viewed October 16, 2019].

17. Judgment of Consiglio di Stato No. 3058 of 21 June 2017. Available at: https://www.giustiziaamministrativa.it [last viewed October 16, 2019].

18. Judgment of Tribunale Roma of 19 March 2004. Rivista del Notariato, 2004, p. 249.

19. Judgment of Tribunale Bologna-Imola of 2 January 2006. Available at: www.personaedanno.it [last viewed October 16, 2019].

20. Judgment of Tribunale Padova of 15 September 2006. Available at: dejure.it [last viewed October 16, 2019].

21. Judgment of Tribunale Trieste of 28 September 2007. Giurisprudenza italiana, 2007, p. 2739.

22. Judgment of Tribunale Caltagirone of 10 July 2008. Il diritto di famiglia e delle persone, 2009, p. 673.

23. Judgment of Tribunale Prato of 8 April 2009. Giurisprudenza di merito, 2010, p. 102.

24. Judgment of Tribunale Modena of 14 May 2009. Giurisprudenza di merito, 2009, p. 1837.

25. Judgment of Tribunale Varese of 6 October 2009. Giurisprudenza italiana, 2010, IV, p. 846

26. Judgment of Tribunale Varese of 25 August 2010. Giurispudenza italiana, 2011, p. 1805.

27. Judgment of Tribunale La Spezia of 2 October 2010. Nuova giur. civ. comm., 2011, I, p. 77.

28. Judgment of Tribunale Firenze of 22 December 2010. Giurisprudenza di merito, 2013, p. 2375.

29. Judgment of Tribunale Busto Arsizio of 12 October 2011. Available at: dejure.it [last viewed October 16, 2019]. 
30. Judgment of Tribunale Varese of 19 October 2011. Available at: www.personaedanno.it [last viewed October 16, 2019].

31. Judgment of Tribunale Varese of 11 November 2011. Available at: www.personaedanno.it [last viewed October 16, 2019].

32. Judgment of Tribunale Varese of 12 March 2012. Famiglia e diritto, 2012, p. 492.

33. Judgment of Tribunale Roma of 30 May 2012. Nuova giur. civ. comm., 2012, I, p. 1005.

34. Judgment of Tribunale Reggio Emilia of 24 July 2012. Foro italiano, 2013, I, c. 2919.

35. Judgment of Tribunale Novara of 5 December 2012. Available at: www.personaedanno.it [last viewed October 16, 2019].

36. Judgment of Tribunale Perugia of 20 June 2013. Repertorio del Foro italiano, 2014, voce Interdizione, inabilitazione e amministrazione di sostegno, No. 34.

37. Judgment of Tribunale di Roma of 23 September 2019. Available at: http://www. quotidianogiuridico.it [last viewed October 16, 2019]. 